\title{
Women Strengthening Through Information Technology Literacy in Tourist Village
}

\author{
Sujarwo Sujarwo*, Erma Kusumawardani, Tristanti Tristanti, Fitta Ummaya Santi
}

Universitas Negeri Yogyakarta, Indonesia

*Email: sujarwo@uny.ac.id

Submitted: 25 September 2020. Revised: 13 November 2020. Accepted: 13 February 2021

\begin{abstract}
Women have positive potentials that support their strategic role in development. This research aims to analysis implementing information technology literacy model guidelines in empowering women through community-based education and how increasing the knowledge, skills, and awareness of women in managing the productive potential of information technology-based environments. By the research and development method or Research \& Development, this research tries to produce a product and test the effectiveness of the product in accordance with development goals. Women's empowerment activities through information technology including providing information technology-based entrepreneurship motivation, forming business groups, training in information technology-based business management, managing businesses and assisting business groups. Data was collected using the method of observation and interview. The collected data were analyzed with qualitative descriptive. The findings of the study are; 1) implementation program which includes: a. preparation for program implementation which includes program socialization, selection of participants, program objectives, materials, strategies, media, teaching materials, assessment, b. implementation of programs, providing information technology-based entrepreneurship, information technology-based business management training, managing businesses and assisting business groups, c. evaluating the implementation of the program by making direct observations during the process, 2) increasing the knowledge of the culinary group.
\end{abstract}

Key words: empowerment, information technology, literacy, village tourism, women

How to Cite: Sujarwo, S., Kusumawardani, E., Tristanti, T, \& Santi, F. U. (2021). Women Strengthening Through Information Technology Literacy in Tourist Village. Journal of Nonformal Education, 7(1), 112-118.

DOI: http://dx.doi.org/10.15294/jne.v7i1.29277

\section{INTRODUCTION}

Women began to rise and managed to prove that their existence was worthy of being reckoned with. The intelligence and expertise of Indonesian women can no longer be underestimated because they have contributed to development. Women can become strategic actors in development. That all women from different character women are affected to different degree by tourism and tourism development. Not only development in villages, but also national development that can change the lives of Indonesian people for the better and more prosperous (Hemalatha, 2020). Village tourism women have a very strategic role in managing and utilizing the potential of the environment to be more productive. However, many obstacles faced by women in exploiting local potential include women having low access in terms of capital resources, transportation and information, knowledge, and skills that women have in terms of managing local potential is still low. The obstacle factors experienced by these women are inseparable from the position of women which basically has three roles, namely reproductive roles, productive roles, and social roles. Although women have three roles that must be carried out at the same time, it does not rule out the possibility for women to have the opportunity to utilize the local potential of rural tourism.
Women can take advantage of tourism potential, namely the provision of tourism businesses to improve their capacity and develop relationships with tourists (Dermatoto, 2012). However, women in tourism villages are also faced with problems in terms of management of tourism villages due to limited knowledge and skills they have. Also called sustainable approach to tourism development, which includes "empowerment" as a potential benefit to local communities frequented by tourists (Edgell Sr, 2019).

Women are interested in participating in agritourism. While $61 \%$ of the rural women state that agriculture is their natural and traditional line of employment, engaging in agritourism as long as it will be profitable is a welcome development. Such number is enthusiastic to get on full-time agrotourism enterprise (Uduji et al., 2020). Rural women faced several problems, including limited professionalism to manage business activities that support tourism, production factors and product marketing are still limited or substandard; cultural background and perception of some rural communities that are still gender biased; limited funds to provide facilities and infrastructure for attractions, cooperation and coordination between sectors / agencies that are less intensive so rural women empowerment in tourism need to be improved (Sujarwo, S., Widyaningsih, W., \& Tristanti, 2015). Tourism research is "surprisingly gen- 
der-blind" (Nunkoo et al., 2020). Gender is closely linked to power, control and hierarchies, tourism research has to address these sociological themes as well (Heuwinkel, 2020). Whether research finding, suggested researchers must not ignore socio-cultural facets of empowerment, the degree to which women perceive of themselves as empowered, and more when conducting research on factors affecting women's perception of empowerment (Aghazamani et al., 2020). One of the tourism and financial factors, namely encouraging women's work, and women's share in non-agricultural wage work (Nassani, A. A., Aldakhil, A. M., Abro, M. M. Q., Islam, T., \& Zaman, 2019).

The condition of these women is increasingly narrowing women's opportunities to develop skills due to the increasingly rapid development of information technology. The great aptitude in agritourism skills in the host communities are not gaining from it by rural women, which could be due to the level of investment in it or how it is approached and managed (Uduji et al., 2020). The benefit of women empowerment in tourism also go a long way in mitigating the challenges related to gender bias and inequality. Women operated tourism ventures are found to work in sync with conservation of natural resources and alleviating poverty (Mohanty \& Chandran, 2018). By reason of rapid development of information technology needs to be accompanied by the ability of the community to use it wisely. During this time the existence of information technology has not had a positive impact on community activities, especially for women who are members of the culinary community. The condition of women who are members of the culinary community does not yet have an agreement in the use of information technology. This is because the group does not yet have the ability to use information technology. Technology is the ability to understand the completeness that follows technology such as hardware, software, and ethics in utilizing technology (Endarta Ali, 2016). Information technologies that can provide wider access are computers, the internet, and cellular telephones. The community is included in the category of ICT literacy where they as individuals in using ICT are able to manage, organize, integrate, and evaluate information, build new knowledge and communicate with others so that they can participate effectively in Public (Syarifuddin, 2014). The findings also refer to that the technology development, especially the internet, has contributed so much to its users. The presence of the internet has supported the effectiveness and efficiency of work as well as a means of communication, publication, and information needed by its users (Lynn K. Rhodes, 1992). It cannot be denied that nowadays the internet has become a people's daily need. They recognize that the internet is very useful both to support work, education, and others.

The results of other research showed that, as many as 122 respondents (19.52\%) stated that the internet was very helpful in carrying out their work. Only four respondents $(0.64 \%)$ stated that the internet did not help their work (Syarifuddin, 2014). In addition to the internet, information technology used is cellular telephone, according to research cellphone use as many as 523 respondents $(83.68 \%$ ) use it to make phone calls, following SMS is used by 494 respondents $79.04 \%$ ), then facilities games are used by 163 respondents $(26.08 \%)$, internet facilities are utilized by 128 respondents (20.48\%), then MMS is 75 respondents (12\%) and the last is video call facilities that are used by 22 respondents (3.52 \%) (Syarifuddin, 2014). Thus the use of technology properly will provide convenience and usefulness for the community in carrying out various programs.

People who are members of the community will find it easier to operate various sales activities because they are supported by each member in the community. An educational process by individuals (in this case adults) to become more competent in their skills, attitudes, and concepts of their communities through democratic participation is the meaning of community-based (Suharto, 2005). That is, community-based education can be interpreted as an educational process where individuals or adults become more competent in handling their skills, attitudes and concepts in living in and controlling local aspects of their society through democratic participation. Hence, the purpose of this research is to analysis the implement of literacy of information and technology model in empowering women in tourism village for analysis how this model can increase awareness, knowledge and skills, women in utilizing information technology in managing their potential and business.

\section{METHOD}

The research method used is the method of research and development or Research \& Development $(\mathrm{R} \& \mathrm{D})$. The product produced from this research and development is a prototype model of technology literacy in empowering rural tourism women through community-based education. The method used includes descriptive and evaluative methods. Descriptive method is used to collect conditions that exist in the field. Evaluative methods are used to evaluate the feasibility of a model of empowering rural tourism women through community-based education which is realized in the form of activity and learning guides. The study was conducted in Gunungkidul Regency of Yogyakarta Special Region. Procedure in this study include; 1) preliminary research, 2) design, 3) pro- 
duction of activities and learning guides, and 4) product trials. Data collection techniques used were observation and interview techniques, questionnaire techniques, performance techniques and tests and FGDs. Data analysis techniques are initial condition data analysis and product feasibility data analysis.

\section{RESULT AND DISCUSSION}

Tourism has an important role to play in achieving the core objectives of the 2030 Agenda for Sustainable Development, in particular a commitment to gender equality and the empowerment of women Sustainable Development Goal 5. Lack of knowledge about the use of tourism to achieve Sustainable Development Goal (SDG) 5 - gender equality and empowerment for all women and girls - There are significant gender biases and inequalities in terms of access to work and physical and social resources that can influence women to have vulnerability and greater constraints to enjoying the expected benefits from tourism development (Afenyo-Agbe E.A., 2020). Development should aim to increase the technical, theoretical, conceptual and moral capacity of tourism human resources in order to achieve good performance and achieve optimal results both at home and abroad (Brata \& Pemayun, 2018).

(Hemalatha, 2020) divided into four areas 1) Employment in the formal labour market, 2) Women's activities in the informal sectors and sustainable livelihood, 3) Women's social economic empowerment, 4) Women's influence and decision making around tourism development policy. Employment opportunities (Duffy et al., 2015); entrepreneurial activities and an increase in family income(Xue \& Kerstetter, 2018); enhanced self- (Moswete, N., \& Lacey, 2015) and community-confidence (Kline et al., 2019).

The activity of empowering rural tourism women through information technology is a strategy that is suitable to the needs of women in terms of product marketing. The use of information technology that is not accompanied by knowledge will have a negative impact on people's lives. (Hemalatha, 2020) stated that in new destinations in some developing countries, local residents face disadvantages to enter the formal sector due to low levels of education. There is a growing demand for education and training in communities in and around the destination. Training, especially training for entrepreneurs, has become an essential element for success. Figueroa-Domecq, de Jong, \& Williams (2020) showed that women are positioned as 'less than', and in need of training and support. The status of women in tourism is explored in the same five thematic areas as in the Global Report namely employment; entrepreneurship; Educa- tion and training; leadership, policy and decision making; and community and civil society. The implementation is carried out through the stages of planning, implementation, and evaluation. Information technology training activities went smoothly attended by all training participants. Empowerment activities begin with planning as a basis for implementing empowerment programs. Empowerment activities are carried out using an andragogy strategy or an adult approach. It is intended that the culinary target group has had a lot of experience. The experience that women have is experience in cooking food menus and the ability to use Android but have not been able to use Android as a tool for marketing products. Therefore, it is important to do empowerment for rural tourism women to improve welfare.

Based on this, it can then be accepted as a continuous multidimensional process involving progress of people from a state of helplessness and deprivation to a state where, especially the most marginalized, have greater influence, power and control over their resources is the concept of empowerment (Boley \& McGehee, 2014). From the empowerment activities of rural tourism women have an impact on women namely the awareness of women to continue learning along with technological developments so as to have skills in the use of information technology, the ease of women in marketing or accessing information technology related to the products produced, improving welfare women in the economic field because of the presence of orders which are more neglected by not utilizing information technology. These results are in line with the opinion of Astuti (2008) that empowerment activities and increasing the role of women in tourism will be able to improve: (1) welfare; (2) access; (3) awareness; (4) participation and (5) control of women in tourism development. There is five dimensions of women's empowerment (economic, social, psychological, educational, and political) are examined at multiple scales (self, family, community and society) (Su et al., 2020).

Literacy as social practice is often referred to, implicitly or explicitly, as a cognitive skill accruing to an individual - an autonomous and generic skill (or suite of skills) that, once learned, can be unproblematically transferred from one context to another and applied across a range of knowledge domains and social contexts (Farrell et al., 2020). Moreover, Barton (2017) argues, 'we live in a textually mediated social world, where texts are part of the glue. This is because language and literacy do not only enable communication, but they also produce identity, produce and distribute power, and structure knowledge: 'literacy is bound up in identity, in power and how we act in the world'. The technology literacy model in empowering women is implemented through learn- 
ing communities. Because the future of business opportunities requires intuitive skills, which is an important strategy for entrepreneurs (Aujirapongpan et al., 2020) with the challenges of the very rapid and rapid development of the business world in the field of information and technology. The activities carried out in this stage started with socialization was carried out by introducing the program of activities and asking for input related to the implementation of the program. The socialization was carried out by involving potential participants, village officials, tourism managers and resource persons (businesspeople and experts). Kaushal \& Yadav (2020) showed that from culinary tourism, the food tour agencies must be professional with all certifications and attention must be paid to location of food tastings, as it become the representation. Another findings also indicate customization is the key to positive customer experience, thereby requiring culinary professionals to understand the customer choices and personalize the food tours accordingly. Furthermore, online reputation management is another key area requiring attention as electronic word of mouth plays a major role. Prayag, Gannon, Muskat, \& Taheri (2020) showed that serious leisure and terroir (physical and social) can explain the relationships between prior knowledge, physical environment, service quality and degree of co-creation in cooking class experiences. Recognizing the physical and social aspects of terroir, the findings illustrate how prior culinary knowledge and serious leisure shape cooking class participation and cocreation. Participants who will be empowered in this program are women who already have a culinary business and are part of a culinary group in the tourist village as many as 25 people. These targets already have their own culinary groups and have a communication tool in the form of an android. The purpose of this program is a) women have an attitude in managing their potential, especially in the field of culinary entrepreneurship, b) increasing the participation of rural tourism women in managing local potential by utilizing information technology. Training materials and assistance in technology literacy activities in community-based women's empowerment include a) motivation and culinary entrepreneurship attitudes by utilizing information technology, b) skills in using information technology in marketing culinary products.

Now tourism human resources are urgent, along with a shift in understanding regarding the main factors of production that are no longer dominated by physical products to become human creativity (Brata \& Pemayun, 2018). The strategy used in the implementation of this activity is in the form of training with a focus on adult education. Operationally the strategies applied include problem solving, learning based on experience, learning by doing. The methods used are lectures, group discussions, practice, and mentoring. In the implementation of technology literacy activities utilizing media in the form of laptop, projector, android, and ingredients for herbal medicine. The implementation of technology literacy activities requires teaching materials to guide participants in following training and practical implementation. The teaching material is in the form of technology literacy guidelines which are prepared based on local characteristics and potential. The evaluation referred to in this activity is carried out in the form of monitoring and evaluating activities. Monitoring is carried out during training activities to the assistance stage.

The implementation of technology literacy in empowering women through community-based education is carried out through the stages of socializing activities, implementing activities in the form of implementing technology literacy models and FGD, evaluating. Last, evaluation of technology literacy and product packaging activities is carried out during the training process. The evaluation is done through observation of training participants in conducting practical activities. For the final evaluation of the training, the indicators are as follows:

1) Trainees understand the types of social media.

2) The trainees are able to use one of the social media to be used as a stall selling pindul herbal medicine.

3) The trainees are able to determine the right and attractive packaging for the herbal medicine to be marketed.

4) The trainee is able to determine the selling price of the medicinal herbs.

5) The trainees are motivated and have high enthusiasm in participating in the training.

In the implementation of empowerment activities must involve the full participation of participants to provide maximum knowledge. The material provided in the implementation is the provision of information technology-based entrepreneurship motivation, forming business groups, training in information technology-based business management, managing businesses and assisting business groups. Motivation activities in empowering women are very important to do to provide entrepreneurial provisions in the target group. The motivation that is built must be intrinsic motivation, namely the existence of a strong will to carry out entrepreneurship activities based on information technology. The next activity is the formation of groups in business management. The groups formed were 5 groups with each group consisting of five members. The women will work more 
optimally if they work in groups or communities. This is due to the nature of women who feel more comfortable working together rather than working independently. This is what distinguishes the nature of the work of women with men. The grouping of the roles of women and men in life actually starts from human thoughts that are still very simple in nature, where people learn from what they see in their lives. In this condition, there is a division of work between women and men biologically. Thus, appears the type of outside work (public) and domestic work. Socialized by their environment, women's lives tend to be in groups, managing food and medicine. This is different from men who work outside freely, the environment of men socializing their nomadic life (Probosiwi, 2015).

Women who have been regarded as the second class, have begun to shift their existence into empowered women. Annes, A., \& Wright (2015) argue that women's empowerment, to the creation of space, or "a room of one's own" where women can pursue their personal interests and make decisions in the absence of interference from other actors in the community. This is evidenced that women have a culinary business which can provide additional economic needs for the family. Sarr, Sène-Harper, \& GonzalezHernandez (2020) argue that a form of empowerment that is better aligned with their social representations as a catalyst for their capacity to carve a meaningful space in tourism. Thus, women have the same role as men and have the same opportunities as men in managing tourist villages. The same opportunity means that both have the same active participation in managing tourism villages. These findings are in line with the goal of women's empowerment to improve the status, position, and condition of women in order to achieve equal progress with men (Sujarwo dan Wibawa, 2013)

The next stage is training in the use of information technology skills for rural tourism women. Nagy, Oláh, Erdei, Máté, \& Popp, (2018) showed that by using technology with more efficient production processes, and achieving better productivity and economies of scale, might also result in increased economic sustainability. Movono \& Dahles (2017) suggested that it is hoped that useful steps can be made to focus on village-based institutions to support empowerment efforts. Strategies undertaken such as peer training should be initiated through pre-existing structures to initiate discussions and negotiations for developing and empowering small businesses among indigenous peoples. Zulkifli, Permata, \& Bakhri (2019) said there is a significant and positive impact on the potency of culinary travel in developing sharia tourism. So, in training activities more is given to practical material in the hope that the target group will be easier to ac- cept various materials, considering the target group is adults who need more intensive study assistance. The next stage is the management of information technology-based entrepreneurship with assistance to culinary groups. This is important to continue to maintain the motivation and attitudes of information technology-based culinary businesses. This is in line that women's empowerment in the tourism sector is more emphasized: 1) organizing and managing the process which involves efforts to change attitudes after so long the dominance of men in many occupations; 2) inventory process related to efforts to provide opportunities for women to develop their abilities so that they can participate in the field of community development; and 3) delivery process which includes efforts to provide opportunities for women to participate and play a role in the field of tourism development related to accommodation, restaurants, travel agencies, and the development of various cultural products in the form of arts and traditions as a tourist attraction (Jamieson W, 1995). Setiawan (2020) showed that the optimisation technology literacy utilisation application in tourism create skilled-human resources in the industrial revolution era 4.0. Moreover, Sariwulan, Suparno, Disman, Ahman, \& Suwatno (2020) showed that digital literacy also related with technology information literacy has the greatest influence on the performance of entrepreneurs. The research results show that digital literacy has the greatest direct and indirect influence on the performance of entrepreneurs; this shows the essential contribution of digital literacy in developing business and marketing networks. In the human resources economy, the skills of an entrepreneur can be learned, educated, and developed (Popescu et al., 2020). Competencies always important because entrepreneurship is for a unique person an ability to take advantage of opportunities and courage to take risks. The condition makes not all starters of the business a success. Thus, empowerment activities will run well if it starts from planning to evaluation. In the empowerment of women based on information technology in the tourism village, it gives a new understanding to the target group to continue learning.

\section{CONCLUSION}

Women are figures who have a strategic role in development efforts, although there are still many strategic issues such as gender injustice. In this article, researchers have positioned and examined the position of women in gender, so that researchers focus more on the positive potential that can be developed. Through this research, the researcher concluded that tourism management cannot be separated from women as agents of development. This is the basis for 
researchers to develop to strengthen the role of women through strengthening technological literacy, especially in culinary management in tourist attractions through training activities as an implementation of the model developed. it turns out that educational efforts through training activities developed for women can help improve skills and further improve economic standards. Implementation of information technology literacy is very beneficial for culinary services groups in the tourist village. The activity is carried out with several stages started with planning until evaluating.

\section{REFERENCES}

Afenyo-Agbe E.A., A. O. (2020). Promoting Gender Equality and Women's Empowerment Through Tourism in Africa: Towards Agenda 2030. Empowering African Women for Sustainable Development, 121-132.

Aghazamani, Y., Kerstetter, D., \& Allison, P. (2020). Women's perceptions of empowerment in Ramsar, a tourism destination in northern Iran. Women's Studies International Forum, 79(May 2019), 102340.

Annes, A., \& Wright, W. (2015). Creating a room of one's own: French farm women, agritourism and the pursuit of empowerment. Women's Studies International Forum, 5, 1-11.

Astuti, I. D. (2008). Model Pemberdayaan Perempuan Pedesaan di Bidang Pembangunan Pariwisata. Spirit Publik, 4(1), 51-68.

Aujirapongpan, S., Ru-Zhe, J., \& Jutidharabongse, J. (2020). Strategic intuition capability toward performance of entrepreneurs: Evidence from Thailand. Journal of Asian Finance, Economics and Business, 7(6), 465-473.

Barton, D. (2017). Literacy: An introduction to the ecology of written language. Cambridge: John Wiley \& Sons.

Boley, B. B., \& McGehee, N. G. (2014). Measuring empowerment: Developing and validating the Resident Empowerment through Tourism Scale (RETS). Tourism Management, 45(December 2014), 85-94.

Brata, I. B., \& Pemayun, A. A. G. P. (2018). Human Resource Competency Tourism Bali together with ASEAN Economic Community. International Research Journal of Management, IT \& Social Sciences, 5(2), 186.

Dermatoto. (2012). Pemberdayaan Perempuan Dalam Pariwisata Berbasis Komunitas (Studi Kasus Tiga Desa Wisata di Jawa Tengah.

Duffy, L. N., Kline, C. S., Mowatt, R. A., \& Chancellor, H. C. (2015). Women in tourism: Shifting gender ideology in the DR. Annals of Tourism Re- search,

52 , $72-86$. https://doi.org/10.1016/j.annals.2015.02.017

Edgell Sr, D. L. (2019). Managing sustainable tourism: A legacy for the future. Routledge.

Endarta Ali. (2016). Literasi Media Literasi Teknologi Literasi Visual.

Farrell, L., Newman, T., \& Corbel, C. (2020). Literacy and the workplace revolution: a social view of literate work practices in Industry 4.0. Discourse, $O(0), 1-15$.

Figueroa-Domecq, C., de Jong, A., \& Williams, A. M. (2020). Gender, tourism \& entrepreneurship: A critical review. Annals of Tourism Research, 84(May).

Hemalatha. (2020). I Nternational J Ournal of. International Journal Of Multidisciplinary Educational Research, 9(1), 219.

Heuwinkel, K. (2020). Female empowerment in tourism in times of travel bans and afterwards. In Tourism Facing a Pandemic: From Crisis To Recovery.

Jamieson W. (1995). Women's role In Rural Cultural Tourism in Western Canada. In Universal Tourism: Enriching or Degrading Culture. (pp. 9199). Gajah Mada University Press.

Kaushal, V., \& Yadav, R. (2020). Understanding customer experience of culinary tourism through food tours of Delhi. International Journal of Tourism Cities.

Kline, C., McGehee, N., \& Delconte, J. (2019). Built Capital as a Catalyst for Community-Based Tourism. Journal of Travel Research, 58(6), 899-915.

Lynn K. Rhodes. (1992). Literacy Assesment. Heineman Educational Book.Inc.

Mohanty, P., \& Chandran, A. (2018). Poverty Alleviation and Women Empowerment through Tourism Development - an Explorative Study of Model Ventures. Atna - Journal of Tourism Studies, 13(1), Moswete, N., \& Lacey, G. (2015). "Women cannot lead": empowering women through cultural tourism in Botswana. Journal of Sustainable Tourism, 23(4), 600-617.

Movono, A., \& Dahles, H. (2017). Female empowerment and tourism: a focus on businesses in a Fijian village. Asia Pacific Journal of Tourism Research, 22(6), 681-692.

Nagy, J., Oláh, J., Erdei, E., Máté, D., \& Popp, J. (2018). The role and impact of industry 4.0 and the internet of things on the business strategy of the value chain-the case of hungary. Sustainability (Switzerland), 10(10).

Nassani, A. A., Aldakhil, A. M., Abro, M. M. Q., Islam, T., \& Zaman, K. (2019). The impact of tourism and finance on women empowerment. Journal of Policy Modeling, 41(2), 234-254. 
Nunkoo, R., Thelwall, M., Ladsawut, J., \& Goolaup, S. (2020). Three decades of tourism scholarship: Gender, collaboration and research methods. Tourism Management, 78(June 2019), 104056.

Popescu, L., Iancu, A., Avram, M., Avram, D., \& Popescu, V. (2020). The role of managerial skills in the sustainable development of SMEs in Mehedinti County, Romania. Sustainability (Switzerland), 12(3), 1-16.

Prayag, G., Gannon, M. J., Muskat, B., \& Taheri, B. (2020). A serious leisure perspective of culinary tourism co-creation: the influence of prior knowledge, physical environment and service quality. International Journal of Contemporary Hospitality Management, 32(7), 2453-2472.

Probosiwi, R. (2015). Perempuan Dan Perannya Dalam Pembangunan Kesejahteraan Sosial (Women and Its Role on Social Welfare Development). $\mathrm{Na}$ tapraja, 3(1).

Sariwulan, T., Suparno, S., Disman, D., Ahman, E., \& Suwatno, S. (2020). Entrepreneurial Performance: The Role of Literacy and Skills. Journal of Asian Finance, Economics and Business, 7(11), 269-280.

Sarr, B., Sène-Harper, A., \& Gonzalez-Hernandez, M. M. (2020). Tourism, social representations and empowerment of rural communities at Langue de Barbarie National Park, Senegal. Journal of Sustainable Tourism, $O(0), 1-20$.

Setiawan, W. A. (2020). Literacy Utilization of Information Technology for Farmers in Badung Regency, Bali In The. 13(11), 1231-1245.

Su, M. M., Wall, G., Ma, J., Notarianni, M., \& Wang, S. (2020). Empowerment of women through cul- tural tourism: perspectives of Hui minority embroiderers in Ningxia, China. Journal of Sustainable Tourism, $0(0), 1-22$.

Suharto, T. (2005). Konsep Dasar Pendidikan Berbasis Masyarakat. Jurnal Cakrawala Pendidikan, $0(3)$.

Sujarwo, S., Widyaningsih, W., \& Tristanti, T. (2015). The Model of Empowering the Women Victims of Merapi Eruption Through Independent Business Literacy Education. Jurnal Penelitian Humaniora UNY, 20(2).

Sujarwo dan Wibawa, L. (2013). Analisis Permasalahan Perempuan Dan Potensi Lokal Di Kabupaten Gunungkidul Daerah Istimewa Yogyakarta. Jurnal Penelitian Humaniora, 18(2), 166-177.

Syarifuddin. (2014). Literasi Teknologi Informasi dan Komunikasi Masyarakat Pedesaan. Jurnal Penelitian Komunikasi, 17(2), 153-164.

Uduji, J. I., Okolo-Obasi, E. N., Onodugo, V. A., Nnabuko, J. O., \& Adedibu, B. A. (2020). Corporate social responsibility and the role of rural women in strengthening agriculture-tourism linkages in Nigeria's oil producing communities. Journal of Tourism and Cultural Change, O(0), 127.

Xue, L., \& Kerstetter, D. (2018). Discourse and Power Relations in Community Tourism. Journal of Travel Research, 57(6), 757-768.

Zulkifli, Z., Permata, L., \& Bakhri, B. S. (2019). The Potency of Culinary Tourism in Development of Sharia Tourism at Pekanbaru City. Journal of Management Info, 6(1), 1-3. 